Ann. Sci. forest., 1980, 37 (4), 307-317.

\title{
Nectria coccinea infection of beech bark : variations in disease in relation to predisposing factors
}

\author{
D. LONSDALE \\ Forestry Commission, Forest Research Station, \\ Alice Holf Lodge, Wrecclesham, Fornham, \\ Surrey, GU10 4LH, U.K.
}

\begin{abstract}
Summary
Trees with differing intensities of Crypfococcus fagisuga infestation were wound-inoculated with Nectria coccinea and it was found that the size of the resulting lesions was related to the severity of infestation, an effect not connected with the provision of stylet-holes or fissures through which natural infection may occur. This finding, together with observations of lesion development on trees affected by a recent severe drought and on nutritionally deficient trees, indicates that stress in the host can enable $N$. coccinea, a weak parasite, to cause extensive bark necrosis. It is suggested that the existence of different sources of stress may be responsible for the contradictory views on the aetiology of beech bark disease.
\end{abstract}

\section{Introduction}

For over a century workers in Europe have described a variety of beech diseases amongst which the development of bark necrosis is a common factor. Of the many insects and fungi found in the necroses the most consistently reported have been the fungus Nectria spp. and the coccid insect Cryptococcus fagisuga Lind. Since the work of Ehrlich (1934) in North America it has become increasingly acknowledged that these organisms can cause beech bark necrosis, the insect being a predisposing factor to infection by the fungus, but our understanding of their roles has remained imprecise. Indeed it has not been accepted by all workers that either or both of them are the true cause of the condition named «beech bark disease » by Ehrlich (op. cit.).

Ehrlich concluded from surveys and experiments that the fungus now called N. coccinea var. faginata Lohman, Watson and Ayers caused bark necrosis of Fagus grandifolia Ehrh. as a result of infection initiated through minute holes and fissures in the periderm produced by the feeding activities of the coccid. He observed that cortical cells were locally killed near the colonies of the insect but he considered that the development of deeper seated and extensive necrosis required the presence of the fungus. Kunkel (1968), on the other hand, has reported that the coccid alone can sometimes cause severe damage on F. sylvatica, and Braun (1977) has stated that N. coccinea (Pers. ex Fr.). Fries, when present, merely accelerates this damage. Conversely, Lyr (1967) regarded $N$. coccinea as the main causal agent and showed that it could cause necrosis of moisture-stressed bark. 
The disagreement on the aetiology of beech bark disease is not confined to the relative importance of one organism or another. Zycha $(1951,1959)$ reported that bark necroses have occurred after drought years and he suggested that beech bark disease is caused primarily by abiotic factors. Other workers, including Schwerdtfeger (1963) have made similar observations, and further support for the view that the disease is caused abiotically came from Dimitri's (1967) simulation of bark necroses through the application of heat and cold treatments. Paucke (1968) also induced necrosis through cold treatment. Braun (1976) has suggested that the observations upon which the " abiotic view 》 is based can be ascribed either to sun-scorch which is a distinctive condition in its own right or to the influence of abiotic conditions on the course of disease caused by $C$. fagisuga.

In the interpretation of these apparently unrelated findings it has rarely been acknowledged that a given set of symptoms need not result from a disease process which is the same in every case. For this reason I have tried to investigate the possibility that the differing views are to some extent compatible. My investigations consist of studies on the role of $C$. fagisuga, of drought and of nutritional deficiency.

\section{The role of Cryptococcus fagisuga}

This part of the investigation has been reported elsewhere (Lonsdale, 1980). The aim of the experiments was to investigate the possibility that $C$. fagisuga infestation can increase the susceptibility of beech bark to internal invasion by $N$. coccinea. Entry via stylet-holes was by-passed by using wound inoculation.

Wound inoculations were made with $N$. coccinea on trees selected from five classes of $C$. fagisuga infestation (table 1 ). The inoculation technique has been described in detail (Lonsdale, op. cit.). It involved the placing of a cereal grain inoculum under bruised and partially detached areas of bark $11 \mathrm{~mm}$ in diameter. Two isolates of $N$. coccinea (QE $1 b$ and $F r 1$ ) and a control treatment were applied to each tree. The three inoculation sites on the stem were placed at $0^{\circ}$ (north), $120^{\circ}$ and $240^{\circ}$ and

TABLE $1 *$

Wound inoculation : C. fagisuga infestation closses

Inoculation par blessure : classes d'infestation de C. fagisuga

\begin{tabular}{|c|c|c|}
\hline $\begin{array}{l}\text { Class } \\
\text { No. }\end{array}$ & $\begin{array}{l}\text { Infestation } \\
\text { Density }\end{array}$ & Description \\
\hline $\begin{array}{l}1 \\
2\end{array}$ & $\begin{array}{l}\text { Zero/trace } \\
\text { Moderate }\end{array}$ & $\begin{array}{l}\text { Fewer than twelve colonies visible on stem } \\
\text { One to three separate colonies per } \mathrm{cm}^{2} \text { sometimes with a small } \\
\text { proportion of merged colonies over at least } 2 \mathrm{~m} \text { length of stem }\end{array}$ \\
\hline 3 & Heavy & $\begin{array}{l}\text { Six or more separate colonies per } \mathrm{cm}^{2} \text { or large, merged colonies } \\
\text { present over at least } 2 \mathrm{~m} \text { length of stem }\end{array}$ \\
\hline 4 & Very heavy & $\begin{array}{l}\text { Continuous or nearly continuous colonisation over at least } 2 \mathrm{~m} \\
\text { length of stem }\end{array}$ \\
\hline 5 & Light (residual) & $\begin{array}{l}\text { No part of stem as heavily infested as in class } 2 \text { buf old wax } \\
\text { secretion, dimpling etc. suggest an earlier attack equivalent to } \\
\text { « } 3 》 \text { or } « 4 »\end{array}$ \\
\hline
\end{tabular}

(Except in the case of class 1 , trees were selected only if the above descriptions were satisfied on all aspects of the stem.) 
these aspects were combined with the treatment types in a Latin square design. The experiment was replicated at five forest sites on crops ranging from 36 to 49 years of age.

This work was done during the period January 25th to March 14th 1977 and assessments were carried out after 13 calendar months (between February 25th and April 14th 1978). The assessments included the following records : presence of Nectria perithecia, degree of callusing (if any), lesion length and lesion width (minus wound diameter). Also, the increase in diameter of each stem at $1.3 \mathrm{~m}$ height during the experiment was recorded.

The main finding from this work was that the largest lesions occurred on the trees with the most intense $C$. fagisuga infestation (fig. 1). This effect was observed

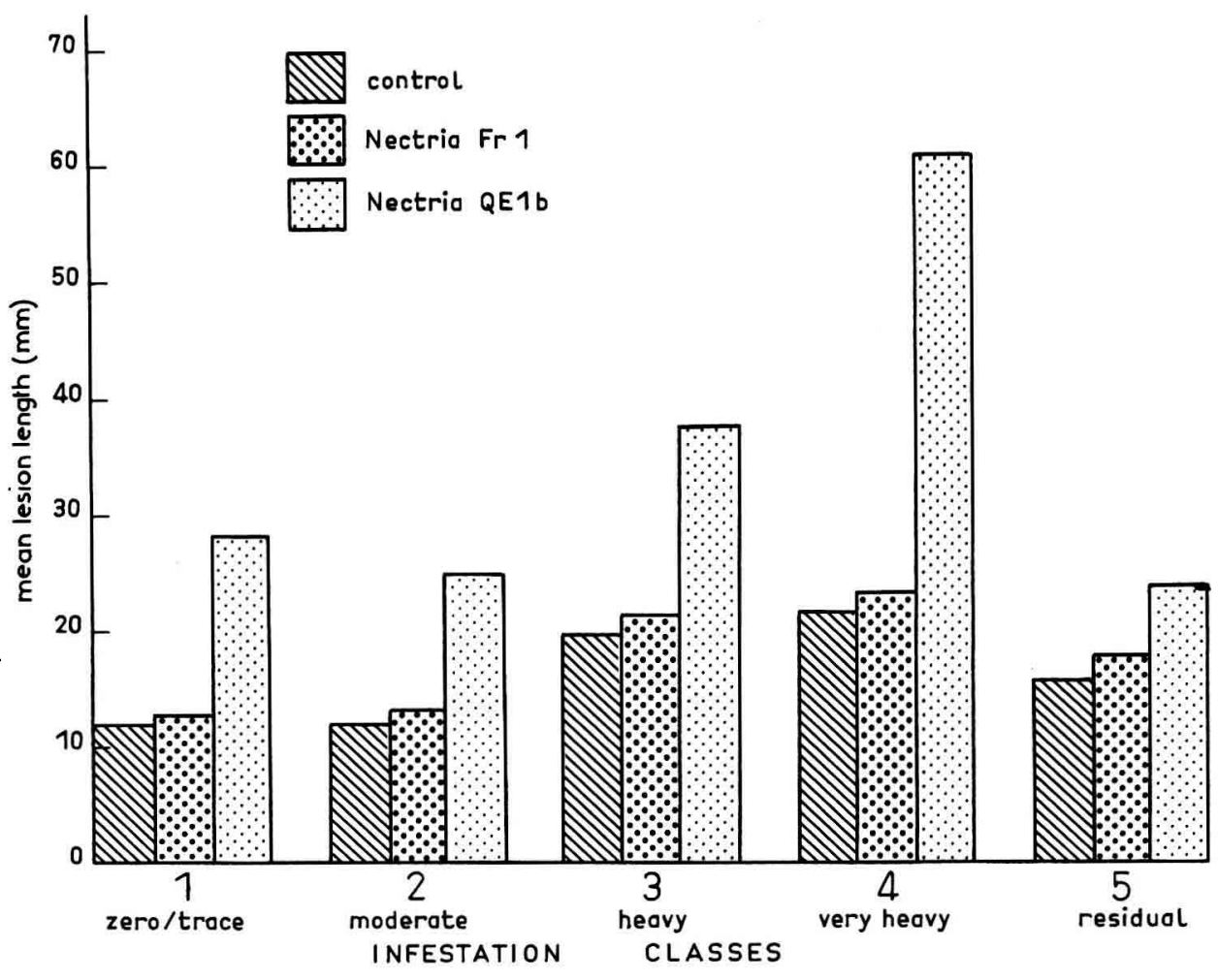

FIG. 1. - Relationship between mean lesion length, inoculation type and infestation class : wound inoculalation. An analysis of variance, carried out on the data for Nectria QE 1b, gave probability values as follows : effect of infestation class $<0.1$ p. 100 , effect of forest site $>20.0$ p. 100 , effect of class $X$ site interaction $>20.0$ p. 100 . Degrees of freedon were $4 / 125,4 / 125$ and $16 / 125$ respectively. Lesion lengths $(x)$ were transformed to $\sqrt{x \times 0.5}$ (from Lonsdale, 1980, Eur. J. For. Path., 10, 161-8).

Relation entre la longueur moyenne de la lésion, le type d'inoculation et la classe d'infestation : inoculation par blessure. Une analyse de variance, portant sur les données relatives à Nectria QE $1 \mathrm{~b}$ donne les probabilités suivantes : effet de la classe d'infestation $<0,1$ p. 100, effet de la station $>20$ p. 100 effet de la classe et de la station > 20,0 p. 100. Degré de liberté 4/125, 4/125 ef 16/125 respectivement, les longueurs de lésion sont transformées par $\sqrt{x+0,5}$. 
most strikingly with the isolate QE 1b, the other isolate not being significantly different in its effect from that of the control. An analysis of variance, carried out on the data for the inoculation with isolate QE $1 b$, showed a highly significant effect of infestation class and no significant effect of forest site or aspect around the stem (fig. 1). It is inte-

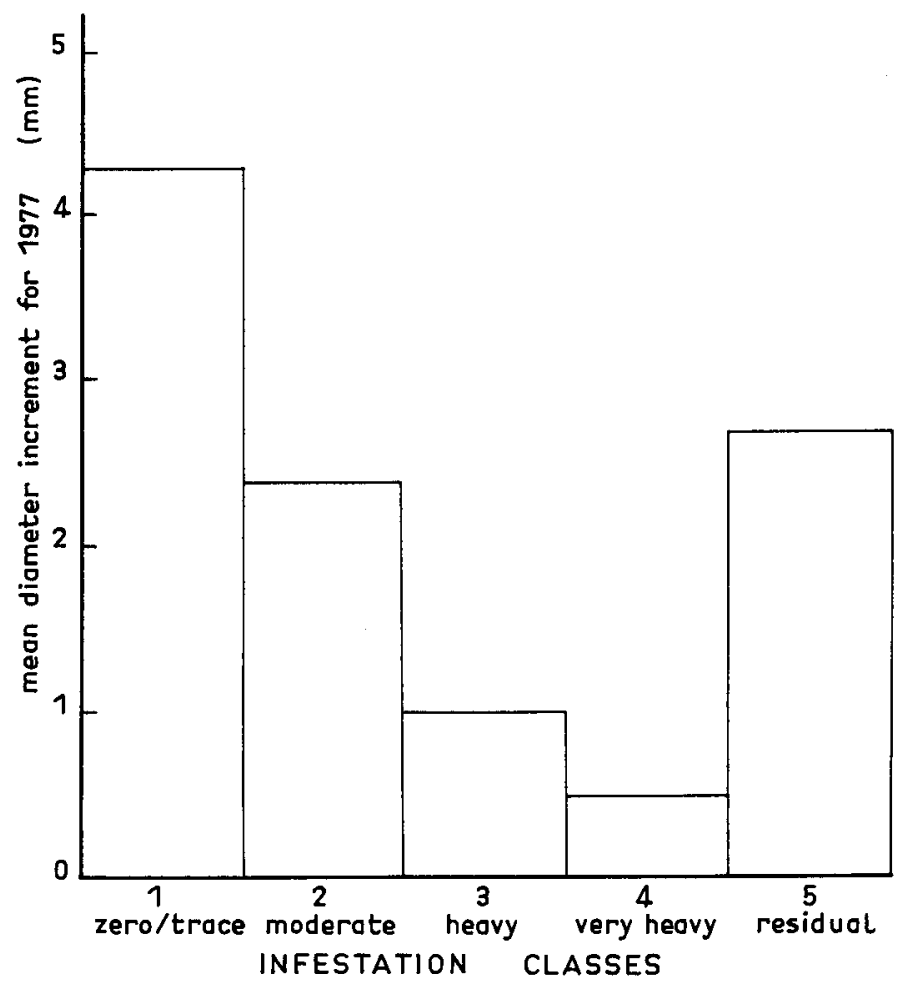

FIG. 2*. - Relationship between infestation class and diamefer growth during wound inoculation experiment

Relation entre la classe d'infestation ef la croissance en diamètre pendant l'inoculation (par blessure) expérimentale

TABLE 2*

Lesion length in relation to diamefer growth during 1977 (all bark classes and all forest sites)

Longueur de la lésion en relation avec le diamètre de croissance en 1977

(toutes classes d'écorce ef toutes stations réunies)

\begin{tabular}{ccccc}
\hline \hline & \multicolumn{3}{c}{ Mean lesion length (mm) } & $\begin{array}{c}\text { No. of trees } \\
\text { represented }\end{array}$ \\
\cline { 2 - 4 } & Control & Nectria QE 1b & Nectria Fr 1 & \\
$\begin{array}{c}\text { Diameter increment } \\
(\mathrm{mm})\end{array}$ & & & & \\
0 & 21.54 & 51.21 & 22.27 & 48 \\
1 & 18.00 & 35.25 & 18.32 & 28 \\
2 & 11.89 & 23.58 & 19.58 & 41 \\
$3-6$ & 12.83 & 25.00 & 13.49 & 12 \\
$7-10$ & 10.67 & 21.50 & 9.83 & \\
\hline
\end{tabular}

* From Lonsdale (1980), Eur. J. For. Poth., 10, 161-8. 
resting to note the low value for mean lesion length in the class 5 trees which had at one time carried a much higher $C$. fagisuga population than at the time of inoculation.

The diameter increment showed an inverse relationship with the severify of C. fagisuga infestation (fig. 2) and with lesion length (table 2). The weak cambial activity in the class 4 trees was also reflected by the frequent absence of callusing around the lesions. Trees in class 1 produced strong callusing, while infermediate activity occurred in class 2 and 3 trees.

\section{Observations on drought-stressed and nutritionally deficient trees}

In 1975 and 1976 there was a prolonged period of low rainfall in England, culminating in a severe drought in the summer of 1976. These conditions caused the early defoliation of many beech trees and the death of some during that summer. Bark necroses and sap exudations appeared on some trees during the autumn and on many more trees during the 1977 growing season. Nearly all of these trees were near, at or beyond maturity and very few of them carried more than a very light infestation of C. fagisuga (fig. 3).

During a survey of symptoms on these affected beech we collected samples from bark necroses on seventy-two trees at eight sites in south east and south west England. The samples were surface sterilised using propylene oxide vapour and plated out on 2 p. 100 malt extract agar. This involved only one or two necroses per tree and only represented some of the trees in the survey, but it indicated that $N$. coccinea was the only fungus isolated with consistency from the necroses. Various other fungi, especially species of Candida, Epicoccum and Aureobasidium were present in many of the necroses but no single species apart from $N$. coccinea occurred in more than 13 p. 100 of samples.

A separate set of samples was taken from drought-affected trees during the winter of 1978/79. Fifty-two trees were sampled in two sites, the sampling being part of an experiment which had involved the trial use of fungicide sprays on post-drought necroses. The fungicide used was carbendazim hydrochloride and if had been applied in different solvent mixtures to the bark surface in spring 1978. In this sampling seven or more necroses from each tree were tested, a much more intensive sampling than that carried out in the post-drought survey. The percentage of samples from which Nectria was isolated was somewhat higher than that obtained in the survey, and 100 p. 100 of trees had one or more necroses which yielded the fungus. As in the case of the trees in the first survey, other fungi were frequently present but none was isolated consistently. (The percentage of necroses from which Nectria was isolated was similar in fungicide-treated trees and the unsprayed controls.) The results of these isolation tests are summarised in table 3.

The majority of the necroses on these drought-stressed trees became surrounded by callus during the 1978 growing season. Continued activity of the lesions occurred only on those few trees with 60 p. 100 or more dieback of the crown.

The observation of necrosis on nutritionally deficient trees took place in young stands (planted 1948-49) at Marden Forest, West Sussex, England. It has been shown that, in this area, a number of sharp boundaries exist between trees with normal green foliage and chlorotic trees (Lonsdale, Pratt and Aldsworth, 1979). These boun- 


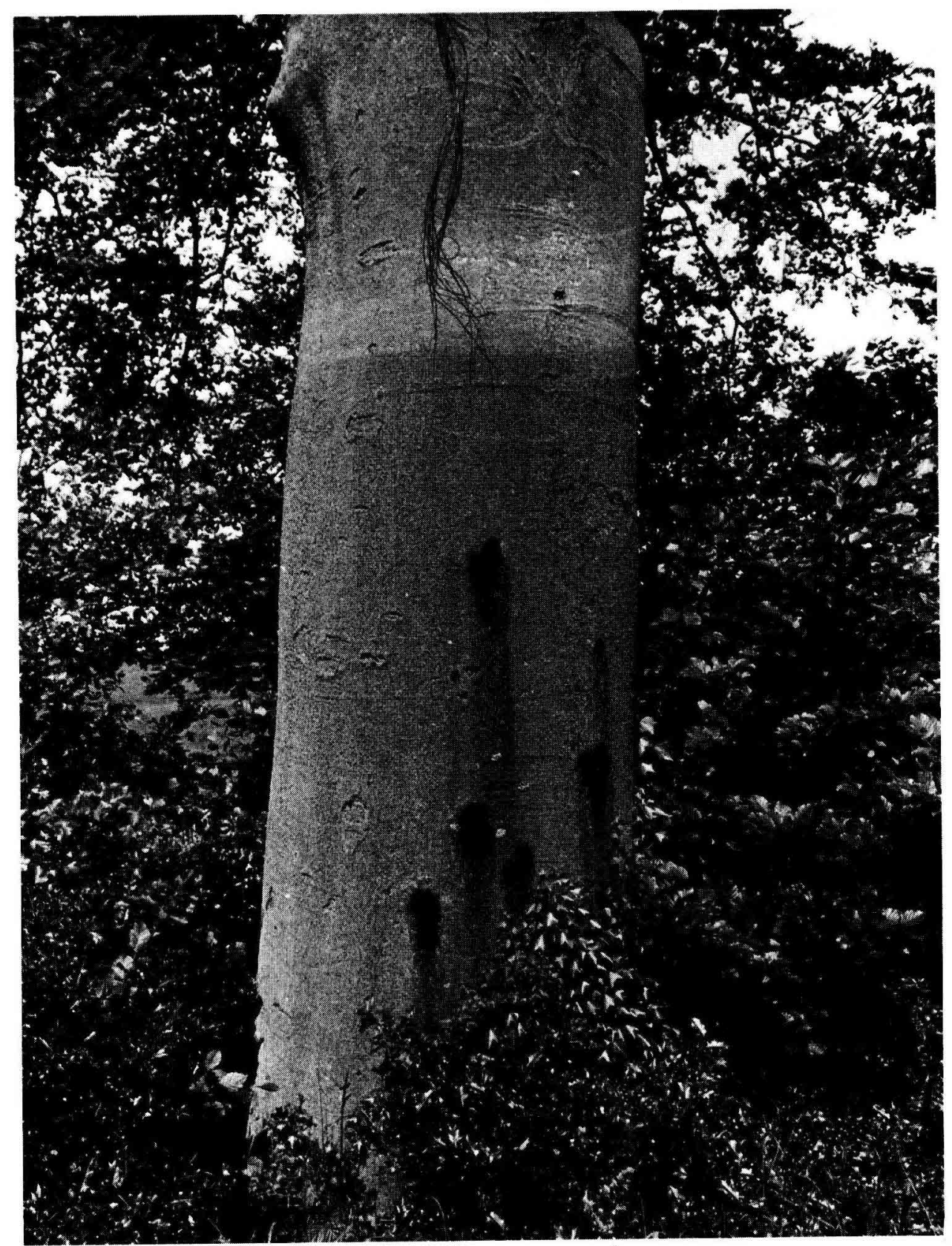

FIG. 3. - Mature beech with bark lesions in the presence of only trace infestation by Cryptococcus fagisuga

Hêtre adulte avec des lésions corficales et la présence très faible de C. fagisuga. 


\section{TABLE 3}

Isolation of Nectria * from bark necroses developing after severe drought Isolement de Nectria de nécroses corticales développées après une sécheresse accusée

\begin{tabular}{cccc}
\hline \hline & $\begin{array}{c}\text { Percentage of bark samples } \\
\text { from which Nectria } \\
\text { isolated }\end{array}$ & $\begin{array}{c}\text { Percentage of trees } \\
\text { from which Nectria } \\
\text { isolated }\end{array}$ & $\begin{array}{c}\text { Mean no. } \\
\text { of samples } \\
\text { per tree }\end{array}$ \\
\hline $\begin{array}{c}\text { Autumn } 1977 \text { survey } \ldots \\
\begin{array}{c}\text { Winter 1978/79 fungicide } \\
\text { trial .................. }\end{array}\end{array}$ & $48.6(72)$ & $48.6(72)$ & 1.0 \\
\hline
\end{tabular}

$(n)=$ no. of replicates.

* In most cases identification was restricted to the imperfect (Cylindrocarpon) stage.

daries are related to the localised presence of chalk fragments throughout the soil profile, a consequence of ancient land use. Beech bark disease is present in these areas and it was possible to compare disease incidence in the «green » and «yellow » parts of the crop. These assessments were carried out by recording disease development on individual trees in a series of transects at $90^{\circ}$ to the nutritional boundary which extended for an equal distance (usually $20 \mathrm{~m}$ ) into the « green » and «yellow » zones.

In table 4 are shown scores for the incidence of moderate and severe $C$. fagisuga infestation (classes 2, 3 and 4 of the inoculation experiment) and the incidence of bark exudations. These scores represent the percentages of live trees with these attributes in the «green » and «yellow » zones at three different sites in the forest. The scores

\section{TABLE 4}

Incidence of moderate to severe $C$. fagisuga infestation and bork exudations on chlorotic and non-chlorotic trees

Incidence d'infestation modérée à èlevée de $\mathrm{C}$. fagisuga ef exudations d'écorce sur des arbres chlorosés ef non chlorosés

\begin{tabular}{|c|c|c|c|c|c|c|}
\hline & \multicolumn{4}{|c|}{ Percentage of live trees } & & \\
\hline & \multicolumn{2}{|c|}{$\begin{array}{l}\text { Presence of moderate/ } \\
\text { severe } C \text {. fagisuga } \\
\text { infestation }\end{array}$} & \multicolumn{2}{|c|}{$\begin{array}{c}\text { Presence of } \\
\text { bark exudations }\end{array}$} & \multicolumn{2}{|c|}{$\begin{array}{l}\text { No. of trees } \\
\text { in sample }\end{array}$} \\
\hline & $\begin{array}{l}\text { Non- } \\
\text { chlorotic }\end{array}$ & Chlorotic & $\begin{array}{l}\text { Non- } \\
\text { chlorotic }\end{array}$ & Chlorotic & $\begin{array}{l}\text { Non- } \\
\text { chlorotic }\end{array}$ & Chlorotic \\
\hline Site $A$ & 27.5 & 27.5 & 10.5 & 16.5 & 215 & 432 \\
\hline Site B & 18.0 & 19.0 & 7.0 & 9.0 & 156 & 202 \\
\hline $\begin{array}{c}\text { Site C } \\
\text { (severe chlorosis) }\end{array}$ & 19.5 & 21.5 & 7.0 & 28.0 & 133 & 155 \\
\hline
\end{tabular}


for $C$. fagisuga infestation were similar on both sides of the nutritional boundary at all three sites, but bark exudation was considerably higher in the «yellow» area at site $C$. It was also higher at the other sites, but less strikingly so. It should be noted that site $C$ showed by far the most striking contrast of leaf colour and size of trees across the soil boundary.

\section{Discussion}

Our understanding of the aetiology of the formation of necroses in beech bark depends on our assessment of the parasitic and saprophytic abilities of the microorganisms which are present in these lesions. Amongst these organisms, Nectria spp. and especially $N$. coccinea are the only fungi which have been isolated with any obvious consistency from necroses on trees carrying heavy infestations of $C$. fagisuga. The findings reported here on drought-stressed trees - trees which carried very low populations of $C$. fagisuga - seem to show a similar association between necrosis and Nectria. It seems reasonable to regard Nectria as the most typical fungal inhabitant of these lesions but this does not imply a unique parasitic role.

When Ehrlich (1934) suggested that $N$. coccinea var. faginata required only the provision of sites of initial entry in order to cause beech bark disease in $F$. grandifolia he did so without comparing its rate of growth in tissues infested and uninfested by C. fagisuga. Parker (1974) wound-inoculated young beech with little or no $C$. fagisuga infestation and found that the resulting lesions were delimited by callus when fairly small and Perrin (1979) has confirmed this. The present findings indicate that the presence of heavy $C$. fagisuga infestation seems to favour rapid and undelimited development of Nectria lesions. It seems likely, therefore, that $N$. coccinea is capable of very limited growth in healthy beech bark and requires a change in the tissues in order to form the extensive lesions characteristic of beech bark disease. In this connection it is worth while to remember Hartig's (1900) statement that the lesions caused by a fungus then known as $N$. ditissima Tul. became extensive and were not delimited by callus when a heavy infestation of $C$. fagisuga (then Chermes fagi Kltb.) was present.

If the development of beech bark disease depends upon a reduction in the resistance of the bark to invasion by a weakly parasitic fungus, it seems reasonable to suppose that other factors which can induce physiological or biochemical change could predispose beech to disorders similar to the beech bark disease recognised by Ehrlich (op. cit.). The presence of necroses containing Nectria on drought-stressed trees suggests that drought is one such factor. As few of these trees were more than very lightly infested by $C$. fagisuga, it must be supposed either that previous infestations had contributed to the predisposition or that the insect was not a causal factor. In either event, the drought was an important factor. In the case of nutritional stress at Marden Forest, the abiotic factor was superimposed upon a typical Cryptococcus/Nectria attack. The apparently enhanced development of necrosis in the chlorotic trees may be analogous to the effect of drought in enabling a weak parasite to produce extensive lesions. It is not clear whether nutritional stress in the absence of heavy C. fagisuga infestation could produce this effect. 
Although these observations suggest that Nectria lesions can be induced by variefy of stress factors, including $C$. fagisuga infestation, it must be pointed out that the lesions produced are variable. There are variations in size and in the presence or absence of callusing, and it could be argued that these differences constitule different diseases. However, the severity of the predisposition and its duration can explain many such differences. Large lesions without callus seem typical of trees with heavy C. fagisuga infestation or very severe drought damage. Smaller, callused lesions, which may be perennial, seem typical of trees with apparently residual infestation in old outbreak areas and of trees which show some recovery from drought camage. If we can improve our understanding of the effects of these variaiions in the severity and duration of predisposing factors, the management of diseased stands could become easier. Also, we may be able to name the various forms of the disease with some precision.

The possibility that $C$. fagisuga infestation, drought, nutritional stress and other factors may all favour the development of bark necrosis suggests that there is compatibility between apparently contradictory views (see fig. 4). There is, however, some

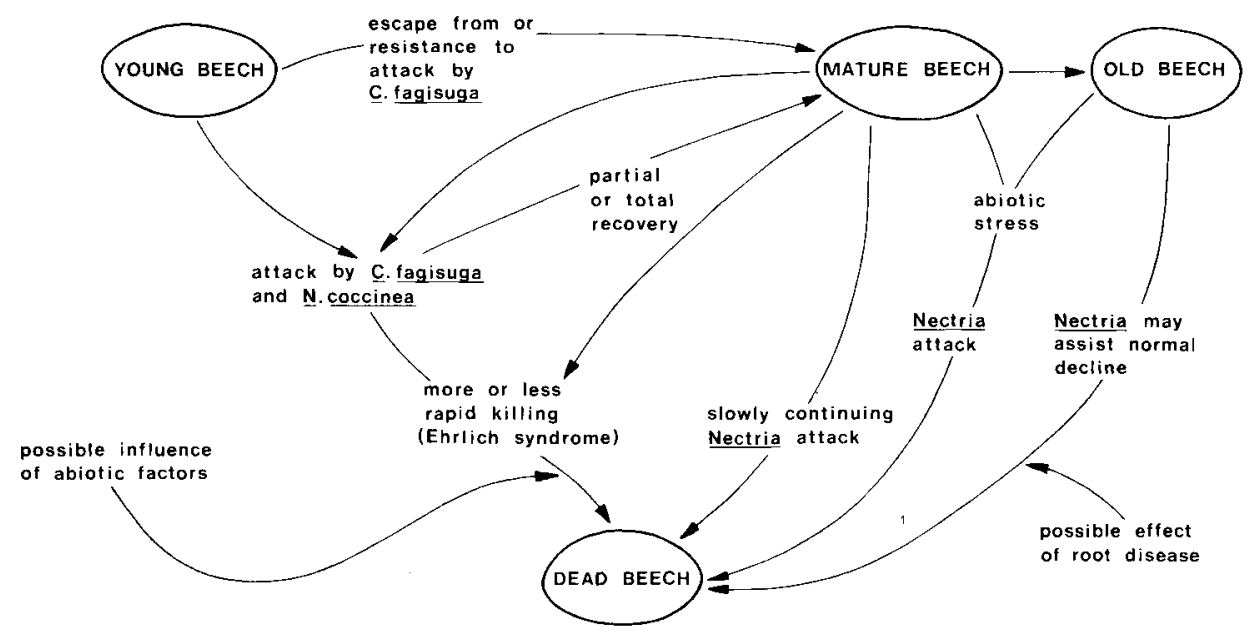

FIG. 4. - Suggested relationships between factors predisposing beech to allack by N. coccinea. Relations suggérées entre les facteurs de «prédisposition 》 du Hêtre aux attaques de N. coccinea.

cause for argument as to the role of $N$. coccinea. The views that $C$. fagisuga or drought can cause beech bark disease in the absence of this fungus have not been based on observations made under axenic conditions. The evidence for its pathogenicity is, however, based mainly on its frequency of association with the disease. This association merits further study and it may be that a worth while understanding of beech bark disease will depend on an improvement in our knowledge of the ecological, physiological and biochemical processes which enable N. coccinea to invade the tissues. 


\section{Acknowledgments}

I am grafeful to Mr. J. E. Pratt for organising field work, to Mrs. M. K. Rawlings for laboratory assistance, to Dr. E. J. Parker and Mr. D. A. Burdekin for discussions, to Messrs. R. Boswell and I. White for statistical analysis and to Mrs. J. G. Anderson for typing the script.

\section{Résumé}

L'infection de l'écorce du hêtre par Nectria coccinea : variations de la maladie en relation avec des facteurs prédisposants

Quelques arbres avec des intensités différentes de pullulation de Cryptococcus fagisuga ont été inoculés par blessure avec Nectria coccineo et on a constaté que la dimension des lésions résultantes était en rapport avec l'intensité des pullulations, un effet indépendant de la quantité de stylets-piqûres ou des fissures par lesquelles une infection naturelle peut se produire. Ce résultat, ainsi que les observations du développement des lésions sur des arbres affaiblis par une période récente de sécheresse grave et sur des arbres souffrant d'une carence nutritive indique qu'un choc dans l'hôte peut permettre à $N$. coccinea, un parasite de faiblesse, de produire une nécrose extensive dans l'écorce. On suggère que l'existence de plusieurs sortes de chocs peut expliquer les avis contradictoires sur l'étiologie de la maladie de l'écorce du hêtre.

\section{Zusammenfassung}

\section{Nectria coccinea - Infektion an Buchenrinde : Krankheitsunterschiede in Abhängigkeit von prädisponierenden Faktoren}

Bäume mit unterschiedlichem Cryptococcus fogisugo - Befall wurden nach Verwundung mit Nectria coccinea beimpft. Die Größe der so hervorgerufenen Nekrosen war abhängig von der Stärke des Lausbefalls, einem Faktor, der unabhängig ist von der Intensität der Rindenverletzungen durch die Mundwerkzeuge der Läuse oder von Rindenrissen über die eine natürliche Infektion möglicherweise verläuft. Diese Resultate Zusammen mit Beobachtungen über die Nekroseentwicklung an Bäumen, die unter schwerer Trockenheit oder Nährstoffmangel litten, weisen darauf hin, daß der Schwächeparasit Nectria coccinea an Bäumen, die unter Stress stehen, schwere Rindennekrosen hervorrufen kann. Vermutlich haben die unferschiedlichen Ursachen des Stresses mit zu den verschiedenen Auffasassungen über das Zustandekommen der Buchen-Rindennekrose geführt.

\section{References}

BRAUN H. J., 1976. Das Rindensterben der Buche, Fagus sylvatica L., verursacht durch die Buchenwollschildlaus Cryptococcus fagi Bär. I. Die Anatomie der Buchenrinde als Basis-Ursache. Eur. J. For. Path., 6, 136-146.

BRAUN H. J., 1977. ... II. Ablauf der Krankheit. Eur. J. For. Path., 7, 78-93.

DIMITRI L., 1967. Untersuchungen über die Äetiologie des « Rindensterbens » der Buche. Forstwiss. Zentl. BI., 86, 257-276.

EHRLICH J., 1934. The Beech Bark Disease. A Nectria Disease of Fagus, following Cryptococcus fagi (Baer.). Canadian J. Res., 10, spec. no., 593-692.

HARTIG R., 1900. Lehrbuch der Pflanzenkrankheiten. 3rd Ed., Julius Springer, Berlin (324 p.), pp. $82-$ 83.

KUNKEL H., 1978. Untersuchungen über die Buchenwollschildlaus Crypfococcus fagi Bär. (Insecta, Coccina), einen Vertreter der Rindenparenchymsauger. Z. Ang. Ent., 61, 373-380. 
LONSDALE D., 1980. Necfria infection of beech bark in relation to infestation by Cryptococcus fagisuga Lind. Eur. J. For. Path. 10, 161-168.

LONSDALE D., PRATT J. E. and ALDSWORTH F. G., 1979. Beech bark disease and archaeological crop marks. Nature (Lond.), 277, 414.

LYR H., 1967. Über die Ursachen der Buchenrindennekrose (Beech bark disease). Archiv. für Forstwesen, 16, 803-807.

PARKER E. J., 1974. Some investigations with Beech bark disease Nectria in southern England. Eur. J. For. Path., 5, 118-124.

PAUCKE Il., 1968. Frostungen an Buchen zur Induktion von Rindennekrosen. Archiv. für Forstwesen, 17, 565-570.

PERRIN R., 1979. Contribution à la connaissance de l'étiologie de la maladie de l'écorce du hêtre. 1. Ełat sanitaire des hêtraies françaises. Rôle de Nectria coccinea (Pers. ex Fries) Fries. Eur. J. For. Path. 9, 148-166.

SCHWERDTFEGER F., 1963. Eine wetterbedingte Baumkrankheit. Die Umschau in Wissenschaft und Technik, 15, 476-478.

ZYCHA H., 1951. Das Rindensterben der Buche. Phyfopath. Z., 17, 444-461.

ZYCHA H., 1959. Stand unserer Kenntnis vom Rindensterben der Buche. Allg. Forstz., 14, $786-789$. 